\title{
INTRODUCTION TO EU RULES ON TAX DISCLOSURE
}

\section{A. SETTING THE SCENE \\ 1. The classical architecture of the international tax system \\ 2. Harmful tax competition \\ 3. Base erosion and profit shifting \\ 4. The post-BEPS era}

B. BEPS ACTION ITEM 12

C. COUNCIL DIRECTIVE (EU) 2018/822 (DAC6)

1. Background

2. DAC6 in a nutshell (a) Reporting duties for
D. JUSTIFICATION OF MANDATORY DISCLOSURE RULES

E. EU LAW LEGITIMATION

F. PROBLEMS/STRUCTURE OF DISCLOSURE OBLIGATIONS AND USE OF THIS HANDBOOK

\section{A. SETTING THE SCENE}

\section{The classical architecture of the international tax system}

The basic prolems with the international allocation of taxing rights and the

knowledge of the need for the avoidance of double taxation have theoretically already been in place since the middle of the 19th century. In earlier times there were hardly any countries that had implemented a personal income tax, in particular in the sense of a modern income taxation, which is based on the economic ability to pay and which also had a transterritorial effect. ${ }^{1}$ The idea of the world-wide income principle in the context of taxation is historically relatively new, and without such a system the question as to in which circumstances possible double taxation occurs and how it can be avoided only arises in exceptional cases (e.g., colonial States that were allowed to retain their own tax system).

1 See in this respect for the history of modern income taxation D'Arcy/Nistotskaya, The Early Modern Origins of Contemporary Tax Systems, ECPR Joins Sessions Workshop 'The New Politics of Taxation', Warsaw, March-April 2015 (to be obtained under https://ecpr.eu/Filestore/PaperProposal/fb909503-7fb8-4073822a-a45dc3458e78.pdf). 
1.02 But with the industrialization at the latest, economic developments blazed a trail towards a greater global integration. ${ }^{2}$ The increasing spread of technical innovations required a global sales market, Great Britain as the central world power of that time, for example, was a pioneer for the doctrine of free trade. The declared aim was to establish a world-wide trade without trade barriers, where the countries outside Europe (especially the colonies) on the one hand took on the role of suppliers of raw materials and food, and on the other took on the role of sales markets. Especially around the verge of the 20th century, economic structures had consolidated, which in some cases also exist today (still or already again), for example in countries with a high dependence on exports. The attempt to build up their own industries, which could work as a counterweight against Western Europe, was only succesful in very few countries (such as Japan). Most States failed and ended up in debt traps and thus went into further dependencies vis-à-vis Europe (e.g., Egypt and other North African countries).

1.03 These developments had not been without consequences. ${ }^{3}$ At the beginning of the 20th century there was indeed a lively trade between many countries already, but the regions of the world also had quite considerable economic differences, which can be seen in the general differences between the (rich) industrialized countries on the one hand and the (poor) developing countries on the other hand. Around 1913 the export quotas of the European countries were at peak level, and the United States (US) had in the meantime developed into the world's largest industrial producer. In 1919 the founding of the League of Nations was a further sign of the international, global networking of nation States. Also when Europe, after the First World War, for its part, was highly dependent on the US because the reconstruction was financed on the one hand with American loans, and on the other hand the US imposed very high tariffs on European imports (history repeats itself?), this was a time, however, when industrial value creation was not only a challenge for the industrialized countries but also brought in some very substantial tax revenue. It was therefore small wonder that the taxing right allocation issues were growing for the first time more urgent than in the decades before.

1.04 An all too general, unilateral and permanent abandonment of the right of taxation on income earned abroad, would, however, have led to the fact that

2 See also for the following Hartwell, Taxation in England during the Industrial Revolution, Cato Journal, Vol. 1, No. 1, Spring 1981, p. 129.

3 See Steinmo, The Evolution of Policy Ideas: Tax Policy in the 20th Century, British Journal of Politics \& International Relations, Vol. 5, No. 2, 2003, p. 206. The article demonstrates that elite ideas about tax policy have changed dramatically over the past century and that these ideas have had enormous consequences for the development of the modern state. 
States would have quickly fallen behind in pecuniary and economic terms. Countries therefore started to co-operate with each other bilaterally and concluded treaties with a two-way effect to avoid or at least mitigate double taxation for their taxpayers. ${ }^{4}$ The first proven double tax treaty, which showed the basic structure of the agreements used today, was probably the domestic (German) tax agreement between Prussia and Saxony from the year 1870. ${ }^{5} \mathrm{It}$ took over components that were already available in rudimentary form in contracts of the Northern German Confederation and led about 20 years later to the conclusion of the first intergovernmental double taxation agreement between Prussia and Austria-Hungary.

This development picked up speed immediately. Quickly, more double taxation agreements between Austria-Hungary and German states were put into force. A first truly systematic approach to the phenomenon of international double taxation, however, did not begin until the League of Nations in September 1921, when it established a panel occupied from the Netherlands, the US, Italy and Great Britain, published a comprehensive report on the causes, the manifestations and possibilities of avoiding international double taxation. ${ }^{6}$

The panel issued its final report ${ }^{7}$ in April $1923 .{ }^{8}$ The report is divided into three parts. In the first part, the economic effects of double taxation were examined, while the second part explains general principles which are to be found in the international tax system of that time and which were fairly predominant. The report assumes that the principle of the economic ability to pay taxes was an inherent principle of taxation. For the allocation of taxing rights to two or more States it was adopted that the guiding principle should be the principle of economic and, interestingly enough, not territorial affiliation. In the third part of the report the possible methods for avoiding double taxation were discussed. The report in that respect already distinguished four

4 A good overview on the history of tax treaties is documented by Friedlander/Wilkie, Policy Forum: The History of Tax Treaty Provisions And Why It Is Important To Know About It, Canadian Tax Journal, Vol. 54, No. 4, 2006, p. 907; see also Jogarajan, Prelude to the International Tax Treaty Network: 1815-1914 Early Tax Treaties and the Conditions for Action, Oxford Journal of Legal Studies, Vol. 31, No. 4, Winter 2011, p. 679.

5 Some authors argue, however, that the treaty between Great Britain and Switzerland (Canton of Vaud) for the prevention of double taxation in respect of death duties was the first official double tax treaty, but this treaty is actually from 1872 (see Jogarajan, The Conclusion and Termination of the 'First' Double Taxation Treaty, British Tax Review, Vol. 3, 2012, p. 283).

6 See fundamentally Jogarajan, Double Taxation and the League of Nations, Cambridge 2018.

7 The original full Report (in English) can be obtained under https://biblio-archive.unog.ch/Dateien/ CouncilMSD/C-216-M-85-1927-II_EN.pdf.

8 For a first contemporary analysis, see Cowcher, League of Nations: Economic and Financial Commission, The Economic Journal, Vol. 33, No. 132, Dec. 1923, p. 566. 
methods: The deduction method (this essentially corresponds to the current tax credit method); the exemption method (which essentially corresponds to the current tax exemption method) for the income earned abroad; and, rounding off, the method of a tax split and the method of the division according to sources (both, as far as one can see, no longer represented today).

1.07 The report thus proves itself overall, also measured against the current understanding and against the background of the historical development of the past decades, as amazingly topical and far-sighted. The Finance Committee of the League of Nations then commissioned senior tax officials in turn from different States to address the problem of double taxation from the very practical (and also fiscal) perspective. The work of the tax officials led finally to the development of a first model tax agreement to avoid double taxation, which was published in $1928 .{ }^{9}$ However, it did not have a significant impact on the the first double taxation agreements concluded in real terms, because the fiscal tendencies of the rapporteurs were too one-sided. In contrast to the professors who had previously written the report, the tax officials were seconded from the participating countries, which led to the fact that the discussion was no longer objective and neutral, but the States increasingly tried to improve their economies and to bring in unilateral fiscal interests.

1.08 Nevertheless, the above-mentioned reports already contained in great detail the basic problems of international taxation, some of which still persist in the present time. The first, obvious problem is the structural economic inequality between States. Industrialized countries on the one hand and developing countries on the other hand (and in the middle, depending on the definition, the so-called emerging markets) have fundamentally different conditions, which in turn is the reason for the different trade interests, which give the world trade its current appearance. Developing countries export, if anything, mainly raw materials and technically simple, but relatively labour-intensive consumer goods (e.g., textiles, toys, etc.). ${ }^{10}$ Industrialized countries, on the other hand, usually export technically sophisticated consumer goods (e.g., medicines, cars, machinery, etc.).

1.09 The most industrialized countries are therefore dependent on raw material imports from developing countries, while the latter preferably import capital

9 The League of Nations' Model Convention can be obtained under https:/www.uni-heidelberg.de/institute/ fak2/mussgnug/historyoftaxdocuments/normtexte/voelkerrecht/V00021.pdf.

10 The problems of developing countries with international taxation were described most recently by Mullins, Center for Global Development (CGD) Policy Paper 166, January 2020, Washington. These problems have not been solved over time, as a comparison with the view of the 1970s shows (see Andic, Tax Problems of Developing Countries, FinanzArchiv / Public Finance Analysis, Bd. 32, H. 1, 1973, p. 155). 
goods in order to adapt their production technically to an acceptable level. This is often accompanied by the fact that the labour market in industrialized countries has a well-educated, academic middle and upper class as a workforce and political, legal, social and economic stability is guaranteed and many more location factors serve as an attraction, while for developing countries the case is often the opposite or at least there is a need for them to catch up quickly. Despite these obvious differences, there are also convergences between both poles. Through foreign direct investment, exports and local investment companies, subsidiaries or permanent establishments companies of the industrialized countries are often invested and already active in developing and emerging ${ }^{11}$ countries. These companies make, through the creation of jobs, the establishment and development of infrastructure and the transfer of know-how and technology, essential contributions for further development on the ground ('assistance to self-help'). Today, many opinion leaders and decision makers recognize in the industry that an active role in the development of emerging markets unleashes innovation potential and ensures success through years. Such an active role can therefore, for example, often be seen in a capital injection or the allocation of licenses (e.g., for the distribution of an asset).

To a certain extent, the so-called tax havens are located 'between the worlds' they also existed around 1920. ${ }^{12}$ Tax haven is a non-technical term, there seems to be no legal-definitory term for States which levy little or no income tax, either on a flat-rate basis or only for certain sectors of the economy. Tax havens can be classified as both residence and source States. They are as old as taxes themselves, and they are often in competition with each other. However, when in a free economic area there are various providers who offer similar products, this usually lowers prices. Tax havens try to circumvent this competition problem. It can be observed that tax havens were and are emerging, with special business models, which specialize in certain activities or which are aimed at customers from certain countries or groups of countries. It can also be observed that the Organization for Economic Co-operation and Development (OECD) and other international organizations and interest groups fight against tax havens. ${ }^{13}$ They place massive political or economic pressure on tax havens and work to ensure that they abandon or adapt their business model.

11 The special tax problems of emerging countries are addressed by Barker, An International Tax System for Emerging Economies, Tax Sparing, and Development: It is all about Source!, University of Pennsylvania Journal of International Law, Vol. 29:2, 1997, p. 349.

12 For the problems caused by tax havens, see Dharmapala, What problems and opportunities are created by tax havens?, Oxford Review of Economic Policy, Vol. 24, Issue 4, Winter 2008, p. 661; see also the interesting study performed by Otto et al., Tax Avoidance, Tax Evasion and Tax Havens, Vienna 2015 (can be obtained under https://www.arbeiterkammer.at/infopool/wien/Studie_tax_avoidance.pdf).

13 See Jackson, The OECD Initiative on Tax Havens, Congressional Research Service Reports, 2010. 
Only economically strong tax havens can resist this pressure. Predestined as tax havens are therefore States that have a large sovereign State behind them, and who focus their business on customers which are not located in the same territory.

1.11 This finding leads on to the second problem, that industrialized countries are more likely to be States of residence in global terms than developing countries, at least as far as prosperous companies are concerned. Typically, therefore, there are a large number of companies, which are subject to an unlimited tax liability in these countries, which according to the principles explained above, are taxed according to the world-wide income principle. Developing countries on the other hand are traditionally mostly source countries, in which many companies are invested and which are only subject to the limited tax liability, and which often simply generate too little tax revenue across the board.

1.12 Even if tax rates in developing countries are usually below the tax rates in the industrialized countries and the companies should therefore be tempted to shift as much taxable earnings as possible to the low-tax State, this alone as a strategy does not lead to a reduction in the tax burden as long as it is not possible to associate a higher added value with the activity carried out in the developing country. The value added by the companies carried out in developing countries were historically often so-called routine activities. ${ }^{14}$ Companies that are practising routine activities or functions (e.g., intra-group services, services provided within the group or simple sales functions), do not have any significant assets and bear only minor risks. The profit attributed to these companies for tax purposes is therefore considerably lower than if the considered company would act as a so-called strategy company. A strategy company performs the functions that are decisive for the success of the group, bears the significant risks and has the essential material and financial resources and intangible assets (central enterprise in the group). Both terms, routine company and strategic player, are technical terms from the law of transfer pricing and serve to the classification of companies in the economic value chain. In any case, around 1920, strategic players were in traditional developing countries hardly to be found. Tax shortfalls in the developing countries, moreover, often resulted from an often imperfect tax system, an inefficient tax administration and the related insufficient enforcement of tax claims. Furthermore, due to a potentially high shadow economy, there was a high risk of an associated turnover and income tax loss.

14 As regards transfer pricing problems with developing countries in particular, see the Final Report "Transfer pricing and developing countries' as of 2011, which was commissioned by the European Commission within the framework of its Tax and Development policy agenda with support of the European Parliament. The Report can be obtained under transfer_pricing_dev_countries.pdf (europa.eu). 
While the industrial nations already in the allocation discussion of the 1920s, but also in the following times referred to the classical arguments for the world-wide income principle (use of local infrastructure, creation of valuable intangible assets, use of the high-level labour market, etc.), the developing countries explained further covetousness with regard to distribution of tax claims regularly with the thesis that the capital injection or licensing in their economic area was to some extent additional income, which was exclusively available on the market of the respective developing country. The industrial nations on the other hand, argued that in a market economy system the majority of the income always comes from the expansion of existing markets or the development of new markets. However, this would apply to all sales markets and changes nothing with respect to the fact that the emphasis on generating income from capital assets and licensing to a certain extent is always with the 'producer'. Against this background, the core question of any allocation of taxing rights between two States is how many withholding tax rights the States wish to grant each other, because a complete abandonment of the rules on the unlimited tax liability is obviously not an option from the outset.

If a company is located in a State (either because of a registration, either by virtue of the seat, or by virtue of a similar, comparable feature), most countries that levy income taxes will subject this company to a variation of unlimited tax liability. There is (and was) agreement in principle on this. The situation is different with regard to withholding tax rights. If we look at two industrialized nations facing each other in terms of the economic performance, and the structure of the economy is comparable, the States involved will usually jointly promote the interest of the limitation of the withholding tax, so that none of the participating countries unduly loses tax revenue. In the case of the developing countries, on the other hand, there is a very fundamental economic imbalance to their disadvantage. The import surplus of these countries would create a mutual surrender of withholding tax rights only to the industrialized country, which is not to the benefit to the developing country, and which is to a certain extent the 'Root of all Evil' in global tax allocation debates: The interest of the developing countries aims at achieving the greatest possible maintenance or extension of the rights of withholding tax, whereas it is the tax policy of the industrialized countries, on the other hand, to reduce precisely these rights. ${ }^{15}$

15 See for arguments in this direction Graetz/O'Hear, The 'Original Intent' of U.S. International Taxation, Duke Law Journal, Vol. 46, 1996-97, p. 1021; see also Avi-Yonah, All of a Piece Throughout: The Four Ages of U.S. International Taxation, Virginia Tax Review, Vol. 25, 2005-06, p. 313. 
1.15 Having said that, the States of the world agreed in the 1920s in foreign policy on the one hand bilaterally, on the other hand to a certain extent implicitly by de facto action or acceptance of the compromise that the industrialized nations or residence States in principle retain the full right of taxation for international tax issues and that therefore the international tax system should be left as it was. ${ }^{16}$ On company level there are only two exceptions, one being that if the threshold for establishing a permanent establishment at source is exceeded and, on the other hand, where direct investments were made through shareholdings, the granting of capital or licences in the source State, which demonstrates a certain participation in the on the market in the source country. In this respect the right to tax at source can be restricted, however, by giving the source State limits for determining the tax rate. In a nutshell: The residence States should in principle be allowed to levy taxes on income, while the source States as market States have the privilege of turnover tax (as well as any customs duties and other import duties), which should cover the resident companies for their supplies and other benefits in the source State. ${ }^{17}$ These considerations then led to the following efforts of the OECD for the development of a model tax convention on the avoidance of double taxation, which became a world-wide success story.

\section{Harmful tax competition}

1.16 It has never been easier than today to transfer substantial assets abroad within seconds. The mobility of taxpayers has also reached unprecedented levels. The combination of these two factors, especially against the backdrop of globalization and the resulting intensified competition between companies, but also the competition for qualified, highly paid workers, leads almost inevitably to taxpayers - especially in the corporate sector - looking for ways to minimize their tax burden or, in extreme cases, to avoid it altogether, be it via transfer pricing, via classic tax arbitrage, via hybrid vehicles or instruments, via base companies, trust constructions and the like. Naturally, this is a thorn in the side of the States involved, even if tax minimization or tax avoidance is expressly legal in many countries.

1.17 Apart from this, however, it is also true that the States, which at least at the outset face each other in the community of States as legal entities with equal rights, have entered into tax competition with each other in the form of a 'race

16 See for a general explanation with views also on the current situation of the 2020s compromise Elliffe, Assessing the Flaws in the 1920s Compromise in the Times of the Burgeoning Digital Economy and the Great Lockdown, Bulletin for International Tax 2020, 4 November 2020.

17 See Woodward, The evolution of the international corporate tax regime, 1920-2008, in: Eccleston/Elbra (eds.), Business, Civil Society and the 'New' Politics of Corporate Tax Justice, 2018, p. 22. 
to the bottom' in terms of tax concessions, the end of which is still not in sight. ${ }^{18}$ All this ultimately leads to a situation in which States compete for economically active and financially strong taxpayers, because otherwise it would no longer be possible to adequately cover the steadily increasing demand for financial resources, particularly in the light of the most recent COVID-19 crisis. First and foremost in welfare States, which as high-tax countries are particularly dependent on competitive neutrality and extra-tax incentives to attract taxpayers, this is demonstrated almost daily anew and probably also explains the verve with which countries like Germany or France have addressed these issues in the past despite the steadily rising domestic tax revenues.

Against this background, it is not surprising that international tax planning has become much more attractive and relevant in practice in recent years. The increasing density of regulations, the coexistence of national tax jurisdictions, the allocation of taxation claims between States through double taxation agreements and also purely factual difficulties (such as language barriers or different cultures) have led to a complexity that is not always easy to understand, even for those in the know. In addition, the international mobility of taxpayers and sources of income has led to conflicting reactions on the part of the tax authorities, which have not exactly led to a simplification of tax law and a more practical application.

However, the basically understandable competition of States for taxpayers and taxable substrate is only one side of the coin. If the totality of government measures reaches an intensity that is capable of deliberately preventing taxpayers from investing in other countries, this results in so-called harmful tax competition, which can no longer be desirable from the point of view of the community of States and also from the point of view of the OECD. Only in extreme cases are the countries addressed typical tax havens. Even within the European Union, the OECD has already identified a whole series of harmful tax practices by Member States in recent years. ${ }^{19}$

Over the decades, the OECD and, somewhat later, the EU Commission have also addressed the economically undesirable problem of harmful tax competition with different approaches. In the past, the focus of attention and criticism was solely on the national level. As early as 1998, the OECD issued

18 See fundamentally Faulhaber, The Trouble with Tax Competition: From Practice to Theory, Tax L. Rev., Vol. 71, 2018, p. 311.

19 As regards tax competition within Europe, see fundamentally Schön (ed.), Tax Competition in Europe, Amsterdam 2003; see also Lampreave, Fiscal Competitiveness versus Harmful Tax Competition in the European Union, Bulletin for International Taxation, Vol. 65, No. 6, 2011. 
its report 'Harmful Tax Competition - An Emerging Global Issue', 20 in which it sought for the first time to record the harmful elements of international tax competition in a truly systematic way. To this end, guidelines were issued that provided for the fundamental elimination of harmful tax practices by 2005 at the latest. In addition, the 'Forum on Harmful Tax Practices' was founded as an OECD working group. It is to this group that we owe the preliminary work on co-operation between tax authorities in tax matters, which now extends from general legal and administrative assistance to joint audits.

1.21 In recent years, however, the discussion has taken on a different tone and has focused not so much on the States, but rather on multinational companies, which, especially through transfer pricing and preferential tax regimes, have achieved in some cases almost 'indecent' corporate tax rates in the low single-digit range. Spurred on by dubious media reporting, it was primarily US multimedia groups that first came to the public's attention, and as a result the EU Commission rediscovered, from around 2013 onwards, the legal institution of prohibited State aid for tax law and has since used it quite successfully. ${ }^{21}$ Intellectual property (IP) boxes in particular, but also other preferential tax regimes, and above all the advance rulings associated with them, will therefore soon be a thing of the past in Europe from the point of view of illegal subsidies under EU law, or at least their effect will be significantly reduced. ${ }^{22}$

1.22 On 6 December 2012, the EU Commission launched an action plan to strengthen the fight against tax fraud and tax evasion, which contains 34 individual proposals in this area. ${ }^{23}$ It is supplemented by a recommendation of the same date on aggressive tax planning, which focused in particular on the revision of the income tax Directives and the inclusion of general and special anti-abuse clauses in double tax treaties. ${ }^{24}$ Another Commission Recommendation of the same date deals with the good governance of third (i.e., non-EU) countries and aims to encourage them to adopt minimum standards in the tax area (e.g., linking to criteria of the so-called EU 'Code of Conduct

20 OECD, Harmful Tax Competition - An Emerging Global Issue, 19 May 1998, Paris; critical review by Avi-Yonah, The OECD Harmful Tax Competition Report: A Tenth Anniversary Retrospective, Brook. J. Int'l L. 34, No. 3, 2009, p. 783.

21 See Bal, Tax Rulings, State Aid and the Rule of Law, in: van Brederode (ed.), Ethics and Taxation, 2020, p. 359.

22 As regards the special problem of and the interdependencies between tax competition and EU law, see fundamentally Pinto (ed), Tax Competition and EU Law, The Hague 2003.

23 European Commission, An Action Plan to strengthen the fight against tax fraud and tax evasion, COM (2012) 722 final as of 6 December 2012 (the Action Plan can be obtained under com_2012_722_en.pdf (europa.eu)).

24 Commission Recommendation of 6 December 2012 on aggressive tax planning (2012/882/EU), Official Journal of the European Union L 338/41 as of 12 December 2012. 
on unfair tax competition', 25 drawing up a 'black list' of tax havens, linking to criteria of the Global Forum on transparency and exchange of information, ${ }^{26}$ etc.). ${ }^{27}$

This was the environment in which the OECD found itself when it began work on a truly epoch-making project in 2013, namely the action plan against BEPS (base erosion and profit shifting). It was initiated with the aim of combating harmful tax competition between States and aggressive tax planning by internationally active corporations. The BEPS project therefore builds a mental bridge between the above-mentioned approach of the last three decades: On the one hand, the States are taken into account, but on the other hand, so are multinational companies.

\section{Base erosion and profit shifting}

The OECD had presented a comprehensive report to the G20 in February 2013 on the causes and effects of profit reduction and profit shifting by multinational companies. ${ }^{28}$ Based on this report, the G20 gave the OECD a mandate to develop a comprehensive action plan. Germany and the German Federal Ministry of Finance played a key role in (and probably also financed) the preparation of the action plan, which was approved by the G20 in Moscow on 20 July 2013. ${ }^{29}$ In the BEPS project and the concrete development of the action plan, 62 countries participated at the outset. These included all OECD and G20 countries, but also developing and emerging countries. International organizations such as the UN, the International Monetary Fund, the World Bank and the EU were also involved, as were regional tax organizations. The action plan is to be understood as a catalogue of measures against base erosion and profit shifting, on the basis of which effective, internationally co-ordinated regulations against profit reduction and profit shifting were to be developed by the end of 2015 .

25 The Code of Conduct for business taxation was set out in the conclusions of the Council of Economics and Finance Ministers (ECOFIN) of 1 December 1997. A good review of the results of the Code are presented by Nouwen, Inside the Diplomatic EU Code of Conduct Group: 20 Years of Tackling Harmful Tax Competition, Amsterdam 2020.

26 For a comprehensive overview of the exchange of information in direct taxation (and also for the development of DAC in history) see Roman Seer/Sascha Kargitta, Exchange of information and cooperation in direct taxation, in: Research Handbook on European Union Taxation Law, 489 (506).

27 Commission Recommendation of 6 December 2012 regarding measures intended to encourage third countries to apply minimum standards of good governance in tax matters (2012/771/EU), Official Journal of the European Union L 338/37 as of 12 December 2012.

28 The Report can be obtained under SG-report-G20-Leaders-StPetersburg.pdf (oecd.org).

29 The Report can be obtained under OECD-tax-report-G20.pdf. 
1.25 The BEPS action plan included the following 15 measures/action items:

Action Item 1: Addressing the Tax Challenges of the Digital Economy ${ }^{30}$

Action Item 2: Neutralizing the Effects of Hybrid Mismatch Arrangements ${ }^{31}$

Action Item 3: Designing Effective Controlled Foreign Company Rules ${ }^{32}$

Action Item 4: Limiting Base Erosion Involving Interest Deductions and Other Financial Payments ${ }^{33}$

Action Item 5: Countering Harmful Tax Practices More Effectively, Taking into Account Transparency and Substance ${ }^{34}$

Action Item 6: Preventing the Granting of Treaty Benefits in Inappropriate Circumstances ${ }^{35}$

Action Item 7: Preventing the Artificial Avoidance of Permanent Establishment Status ${ }^{36}$

Action Items 8-10: Aligning Transfer Pricing Outcomes with Value Creation ${ }^{37}$

Action Item 11: Measuring and Monitoring BEPS38

Action Item 12: Mandatory Disclosure Rules ${ }^{39}$

30 https://www.oecd.org/tax/beps/addressing-the-tax-challenges-of-the-digital-economy-action-1-2015-finalreport-9789264241046-en.htm.

31 https://www.oecd.org/tax/beps/neutralising-the-effects-of-hybrid-mismatch-arrangements-action-2-2015final-report-9789264241138-en.htm.

32 https://www.oecd.org/tax/beps/designing-effective-controlled-foreign-company-rules-action-3-2015-finalreport-9789264241152-en.htm.

$33 \mathrm{https} / /$ www.oecd.org/tax/beps/limiting-base-erosion-involving-interest-deductions-and-other-financialpayments-action-4-2016-update-9789264268333-en.htm.

34 https://www.oecd.org/tax/beps/countering-harmful-tax-practices-more-effectively-taking-into-accounttransparency-and-substance-action-5-2015-final-report-9789264241190-en.htm.

35 https://www.oecd.org/tax/beps/prevention-of-treaty-abuse-peer-review-report-on-treaty-shopping-9789264 312388-en.htm.

36 https://www.oecd.org/tax/beps/additional-guidance-attribution-of-profits-to-a-permanent-establishmentunder-beps-action7.htm.

37 https://www.oecd.org/tax/beps/oecd-transfer-pricing-guidelines-for-multinational-enterprises-and-tax-admin istrations-20769717.htm.

38 https://www.oecd.org/tax/tax-policy/measuring-and-monitoring-beps-action-11-2015-final-report-9789264 241343-en.htm.

39 https://www.oecd.org/tax/mandatory-disclosure-rules-action-12-2015-final-report-9789264241442-en.htm. 
Action Item 13: Guidance on Transfer Pricing Documentation and Countryby-Country Reporting ${ }^{40}$

Action Item 14: Making Dispute Resolution Mechanisms More Effective ${ }^{41}$

Action Item 15: Developing a Multilateral Instrument to Modify Bilateral Tax Treaties $^{42}$

In this way, the international community of States is responding in a broad international consensus to the observation in recent years that multinational companies are increasingly reducing their tax burden to a minimum by taking advantage of different tax systems compared with companies operating predominantly nationally. The results of the BEPS project therefore aim to reduce information deficits of tax administrations, to link the extent and place of taxation more closely to the actual economic substance, to increase the coherence of the individual national tax systems of the States and to curb unfair tax competition. In principle, this is necessary for several reasons. Of course, BEPS primarily has negative consequences for the Treasury, because harmful tax competition and aggressive tax structuring lead to tax losses that countries cannot afford, especially in times of necessary budget consolidation. But there are also other disadvantages. For example, the competitiveness of companies that do not use such tax arrangements and therefore bear a higher tax burden is reduced. This affects small- and medium-sized companies in particular. In addition, the overarching principle of fair taxation is affected when only a few companies reduce their tax burden to a minimum through complex constructions and others are taxed at the standard statutory rate.

\section{The post-BEPS era}

In the last two decades, information and communication technology has developed rapidly. Computing power and storage capacities have increased exponentially, the production costs for computers have fallen, telecommunications networks and the Internet have spread, and software and data use have been optimized. As a result of this development and the associated transformation process, companies have adapted their existing business models and established new models. The resulting digital economy has produced the

40 https://www.oecd.org/tax/beps/transfer-pricing-documentation-and-country-by-country-reporting-action13-2015-final-report-9789264241480-en.htm.

41 http://www.oecd.org/tax/beps/beps-action-14-on-more-effective-dispute-resolution-peer-review-documents. pdf.

$42 \mathrm{https} / /$ www.oecd.org/tax/developing-a-multilateral-instrument-to-modify-bilateral-tax-treaties-action-152015-final-report-9789264241688-en.htm. 
following business models, among others, as already mentioned in the OECD study on BEPS in its Action Item 1 (Addressing the Tax Challenges of the Digital Economy): 43

(1) in the so-called E-Commerce (this was 'the' buzzword back in the 1990s), goods or services are offered via digital networks and then sold online or offline (e.g., Alibaba or Amazon as online traders or Apple, which sells its goods online and in retail outlets);

(2) in the so-called Online Advertising business, goods or services are advertised via the Internet and the operators of the websites generate advertising revenue or receive a fee for the sale of user data (e.g., Google, Facebook);

(3) in the so-called Sharing Economy, goods or services are exchanged via an Internet platform and the intermediary platform receives a commission (e.g., Airbnb, Uber);

(4) in so-called Cloud Computing, computer services such as computing power, storage or software are offered via the Internet (e.g., Amazon Web Services, Google, Microsoft).

1.28 The digital economy is characterized by a number of key features that are relevant from a tax perspective. Goods and services can be offered easily and quickly across borders in different countries. Companies can carry out business functions from a central location, with no or only the minimal presence of personnel in the sales market (mobility of taxation of the digital economy business functions). With a small increase in staff, companies can increase and maximize the size and reach of their business (scale without mass). Users, for their part, can carry out business transactions globally at comparative ease (mobility of users). Furthermore, the development and use of IP rights (and the resulting dependence on them) plays a major role. Digital companies are often dependent on IP and software and invest in the development of new software products. In addition, the collection and processing of data, especially so-called Big Data, is a decisive factor in the digital economy. Customer data is evaluated to personalize advertising and improve the product range. Finally, network effects are of great importance for companies in the digital economy. The more users there are, the greater the value of the network (e.g., social networks, media sharing sites).

1.29 Because of the above-mentioned characteristics of the digital economy, the following tax problems and questions currently arise: First, there is the

43 https://www.oecd.org/tax/beps/addressing-the-tax-challenges-of-the-digital-economy-action-1-2015-finalreport-9789264241046-en.htm. 
question of how value creation is determined in the business models of the digital economy. Are users and data to be regarded as part of the value creation chain? And if so, what proportion of the total value creation of digital companies is made up of users and data? The users and the data they provide in the source State are not taken into account under current tax rules. Secondly, the question arises as to whether a further tax link or digital tax needs to be created for the digital economy in the source State. Under the current tax rules, a company in the sales market can be taxed in another country if there is a genuine link to that country, e.g., due to a separate company or a permanent establishment. However, the establishment of a permanent establishment requires a physical presence (i.e., a fixed place of business or local employees of the company). In the digital economy, on the other hand, a physical presence is no longer required to do business in another country, which would give rise to a tax liability under the traditional tax rules. The only exception to this are taxes on consumption, in particular value added tax, which has different rules of connection. Thirdly, there is the question of appropriate and 'fair' taxation of the digital economy and the distribution of the tax base in the State of residence of the company and in the source State of the users. These issues related to the taxation of the digital economy represent a major challenge for all parties involved: For the individual States, the tax administrations as well as the companies.

It is immediately clear that dealing with these problems requires a global, internationally co-ordinated solution in order to avoid distortions of competition. The OECD itself had already given itself certain guidelines for the taxation of E-Commerce in 1998 in its so-called Ottawa Taxation Framework Conditions, ${ }^{44}$ on which it intended to base its future initiatives in the tax field. These guidelines can be summarised under five headings:

(1) neutrality: Taxation should be equally designed for both conventional and electronic forms of commerce and for domestic and foreign companies;

(2) efficiency: Compliance costs for companies and administrative costs for tax authorities should be minimized as far as possible;

(3) certainty and simplicity: Tax provisions should be as clear and simple to understand as possible so that companies can anticipate the tax consequences in advance of a transaction;

44 The Report can be obtained under https://www.oecd.org/ctp/consumption/1923256.pdf. The results of implementation regarding the agreed measures were monitored and published in a second report in 2003, see https://www.oecd.org/tax/administration/20499630.pdf. 
(4) effectiveness and fairness: Taxation should provide the right burden at the right time and the potential for tax evasion and avoidance should be minimized;

(5) flexibility: Tax systems should be flexible and dynamic to ensure that they keep pace with technological and commercial developments.

1.31 The OECD, the EU and individual countries have subsequently addressed the issue of taxation in the digital economy, with the aim of developing new tax policies. The OECD developed various points of action to combat tax avoidance and artificial profit shifting within the framework of the Base Erosion and Profit Shifting project. In addition to the central Action Item 1, Action Item 7 (Preventing the Artificial Avoidance of Permanent Establishment Status) has already expanded certain aspects of the concept of permanent establishment in order to take into account - among other things - developments in the digital economy. Accordingly, the OECD Model Convention and the Commentary on it were adapted in 2017.45 According to this amendment, certain facilities (warehouses, distribution centres, purchasing offices or facilities for the procurement of information) in particular will no longer be automatically classified as permanent establishments, but only if the concrete activity associated with them is actually an auxiliary or preparatory activity. For example, a distribution centre of an online retailer in the respective country can therefore establish a permanent establishment.

1.32 Action Item 1 of the BEPS project, which explicitly addresses the tax challenges of the digital economy, discussed various concepts in the field of direct taxation, namely first, the introduction of a 'digital place of business' (digital presence, digital nexus), secondly, the introduction of a withholding tax on certain digital transactions and thirdly, the introduction of an equalization levy on certain digital services. The OECD decided to pursue the issue of taxation of the digital economy and published an interim report in March 2018. ${ }^{46}$ However, this interim report did not contain any concrete, let alone substantial proposals, as positions differed widely between countries. However, the OECD wanted to further investigate two key aspects of international tax law: First, the question of the nexus (i.e., under what circumstances a company in a country becomes liable for income tax or direct taxes in a broader sense) and secondly, the question of profit allocation (i.e., how the company's profit is allocated between countries for tax purposes). The OECD then planned to publish further results in 2019 and to present mutually agreed solutions in 2020 .

45 https:/www.oecd.org/tax/treaties/oecd-approves-2017-update-model-tax-convention.htm.

$46 \mathrm{https} / /$ www.oecd.org/tax/tax-challenges-arising-from-digitalisation-interim-report-9789264293083-en.htm. 
The EU Commission had already gone one step further compared to the OECD and published concrete proposals for taxing the digital economy as early as March 2018. With these proposals, the EU Commission wanted to avoid different and unilateral measures by the EU Member States. The EU Commission is of the opinion that under the current tax rules, value creation in the digital economy (e.g., the value added by the data provided by users) is not duly taken into account and that there is an unjustified discrepancy between the place of value creation and the place of taxation of profits. Under the title of 'Fair taxation of the digital economy' 47 the EU Commission made two legislative proposals for Council Directives: The first proposal was intended as a long-term measure and aimed at introducing a digital permanent establishment (so-called significant digital presence); 48 the second proposal was intended to be a transitional solution from the outset and provided for the introduction of a digital tax on income from certain digital services. ${ }^{49}$

On the one hand, this takes up BEPS Action Item 1 from 2015, which unfortunately did not come up with a recommendation or a concrete result, and on the other hand, it expresses the hope that a broad-based, preferably concerted action by the OECD Member States would find greater international acceptance (even among non-OECD Members). Thus it came to pass that the OECD, in co-operation with the 'Inclusive Framework on BEPS', published the 'Work Programme for the Development of a Concerted Solution to the Challenges of Managing Digitisation of the Economy' in the form of a working paper ${ }^{50}$ on 31 May 2019. The working paper is based on the assumption that an agreement can be reached among the OECD Member States by the end of 2020. Once again, the OECD was putting itself and the Member States under enormous time pressure, which is objectively considered to be artificial. The 'official justification' for this is the 'threat' of individual States to unilaterally switch to or stick with national measures in the event of a failed international consensus-building process.

Unfortunately, it is not possible to verify objectively whether this justification is true or not. It is a fact, however, that in view of the complexity of the issue, it seems completely out of the question that even a solution that at first glance appears to be internationally agreed upon could have consequences that are

47 https://ec.europa.eu/taxation_customs/business/company-tax/fair-taxation-digital-economy_en.

$48 \mathrm{https} / /$ ec.europa.eu/taxation_customs/sites/taxation/files/proposal_significant_digital_presence_21032018_ en.pdf.

49 https://ec.europa.eu/taxation_customs/sites/taxation/files/proposal_common_system_digital_services_tax_21 032018_en.pdf.

50 https://www.oecd.org/tax/beps/programme-of-work-to-develop-a-consensus-solution-to-the-tax-challengesarising-from-the-digitalisation-of-the-economy.htm. 
not completely incalculable for the individual taxpayers and also for the individual States from a macroeconomic point of view. Secondly, it is a fact that a uniform international solution tends to be better than a multitude of individual measures in different countries, even if it must be conceded that the diversity of tax systems already affects taxpayers today and can be handled quite well in practice. But it is also a fact, thirdly, that an international unification of the European countries 'against the United States' makes no sense. The OECD has already warned of a 'tax war' which would probably soon lead to a trade war with the US. One can reasonably have no interest in this, although the US in mid-July 2020 stepped back from the discussion table for a while.

1.36 The above-mentioned OECD work programme outlines various measures that are methodically based on two different approaches (so-called 'pillars') and also have different objectives. On the one hand, primarily with regard to companies that maintain or offer digital business models, the basic concept for the distribution of global taxation rights, which has been widely accepted internationally and is described above, is to be reconsidered and replaced by innovative taxation concepts. On the other hand, and here the work programme goes beyond companies in the digital economy, the previous measures of the BEPS project should be flanked by a world-wide minimum taxation. The work programme will be explained in more detail below, not least because it will be a key element in shaping the new world tax system.

1.37 Although the so-called Pillar $1^{51}$ of the work programme is headed by the taxation of the digital economy, its content differs from Action Item 1 of the BEPS project to the extent that it does not go into the underlying causes of profit relocation in more detail. Three new types of taxation concepts for digital enterprises are presented for discussion, namely the so-called user participation concept, the marketing intangible concept and the concept of a significant economic presence. These three concepts are then described and examined in greater detail by highlighting three different aspects: First, the type of profit-sharing method to be applied, secondly, the new starting points for the taxation of digital services, and thirdly, accompanying measures.

1.38 First, the so-called user participation concept, which is based on a proposal from Great Britain. It is based on the idea that the user participates in the creation and increase in value of the company whose services he or she uses (against payment). In concrete terms, this means that every user resident in a

51 https://www.oecd.org/tax/beps/oecd-invites-public-input-on-the-secretariat-proposal-for-a-unified-approachunder-pillar-one.htm. 
country who enters a keyword in the Google search engine should, according to this concept, improve the precision of the algorithm behind Google with his or her search query and consequently increase the company value of Google. Highly digitalized companies thus create a 'userbase' distributed over many States world-wide, through which data and content are generated and which therefore justifies taxation in these States. However, the value added associated with this cannot be taxed according to the previous taxation concepts because of a too low physical presence in the jurisdictions concerned. As a solution, it is therefore proposed that a modified profit distribution analysis be used to determine that part of the profits generated by a user activity, and this part of the profits should then be distributed to the countries in which the users are resident on the basis of an agreed allocation metric (e.g. sales or turnover).

The second concept, known as the 'marketing intangibles approach', which is favoured by the US in particular, outlines a situation in which a group of companies intervenes from a distance in the economy of a State through targeted sales activities and related measures, creating a user or customer base and other 'marketing intangibles' (i.e., intangible assets created as a result of a company's marketing expenditure) without this value added being taxable. Here, too, the proposed approach is a modified profit distribution analysis in which mechanical approximations are used to determine the profit that can be allocated to the marketing of intangible assets. In a second step, this profit is distributed to the jurisdictions in which the marketing intangibles were generated using an agreed allocation metric.

In the third proposed concept, which is called the 'significant economic presence approach', an economic presence would be taxed - for the first time in the history of tax law and beyond the current permanent establishment concept - as soon as it can be proven that an intended and continuous interaction (e.g., through digital technologies) with a State exists. For the determination of the profit to be taxed, it is proposed that the global profit margin of a group of companies be applied to the turnover within the respective jurisdiction and subsequently modified taking into account certain factors (e.g., turnover, economic goods, number of employees or the size of the 'userbase'). For the appropriate allocation of the profit, a distributive allocation method is proposed, whereby the previously determined profit is distributed to the affected jurisdictions using weighted allocation keys.

Within the framework of all three concepts, the nexus principle (which has been in force for decades, as described above) would have to be changed in order to give the jurisdictions the right to tax the value added generated in 
their respective countries. Proposals in this respect include the modification or extension of the definition of a permanent establishment or the introduction of a new, stand-alone nexus for digital services, which would need to be defined in more detail according to the technology used. Currently, within the framework of a so-called unified approach, it is being discussed to restrict both the scope of the new regulations and the new nexus via turnover thresholds. In general, only groups of companies that operate a 'consumer facing' in the broadest sense are to be covered. Everything that is suitable so that a consumer can use it should ultimately be covered. A limitation to purely digital companies is not to take place, which resumes BEPS Action Item 1: The digital economy today can no longer be ring-fenced from the purely real economy.

1.42 In the market State, in addition to the turnover threshold exceeded there, other factors are to be added, such as click figures or certain value contributions from users, which have yet to be defined, in order to arrive at a taxation right for the market State. If these prerequisites are fulfilled, a total profit of the company is to be determined on the basis of an accounting standard yet to be defined, which differentiates between routine and non-routine profits on a first level. On top of this, a distribution key is then partly laid over all market States, which should ensure a uniform allocation of taxation rights. If one reads the proposals for Pillar 1 impartially, two aspects stand out immediately. The first aspect concerns the fact that 'taxation according to value creation', which was one of the central guidelines of the BEPS project, is not reflected at all in the justification for Pillar 1 . The second aspect concerns the fact that the OECD claims that the high-tax countries will be the winners of the previous proposals. This is prima facie at least astonishing, because ultimately the concept of Pillar 1 amounts to taxation of supply profits, which is a general problem for export nations.

1.43 The so-called Pillar $2^{52}$ of the work programme is intended to ensure - also for the first time in the history of tax law - a global effective minimum taxation of company profits. The background to this idea, which is based on a FrancoGerman proposal, is the assumption that the special features of the digitalized economy allow profits to be shifted to low-tax countries and therefore justify limiting tax competition to a certain minimum level. In this context, two interrelated measures are currently being discussed at the OECD level, namely, on the one hand an extension of the national rules on supplementary taxation and on the other hand a limitation or prohibition of the deduction of

$52 \mathrm{https} / /$ www.oecd.org/tax/beps/oecd-secretariat-invites-public-input-on-the-global-anti-base-erosion-proposalpillar-two.htm. 
business expenses if the effective minimum taxation level is not reached. The impact of these measures on the individual countries and the tax burden on companies will depend significantly on the effective tax level prior to the introduction of the new rules and the global effective minimum taxation level that is being aimed at. At the same time, the full sovereignty of States to set tax rates should be preserved.

The first component (i.e., the extension of national rules on supplementary taxation) specifically provides for the addition of low-taxed profits of foreign subsidiaries of a company to the parent company's profit for the purpose of taxing it, and for this purpose to extend national supplementary taxation along the lines of the US 'GILTI' (global intangible low-taxed income). Whether the income to be added is taxed at the level of the parent company's State of residence or at a lower tax level is currently still open. The type of income should be irrelevant, as should the activity and substance of the foreign, low-taxed company. This is to be achieved by adapting the respective national tax laws, but also requires international harmonization. Within the EU, this would be conceivable, for example, by means of an EU Directive, and in relation to third countries by means of a bilateral agreement within the framework of a double taxation agreement.

The second component provides for limiting the deduction of operating expenses for payments to low-taxed foreign countries. Following the model of the 'BEAT' (base erosion and anti-abuse tax) introduced as part of the US tax reform, this measure is intended to cover profit-reducing payments to foreign (affiliated) companies with the aim of reducing domestic tax liability. The aim is to tax the company's profit before deduction of the said harmful payment. However, this goes far beyond the Nexus approach that has been used to date for licenses and, since it could be designed to be expenditure-oriented rather than profit-oriented, has very significant negative effects with an excessive tendency.

The proposals just outlined for Pillar 2 have four different features, which are $\mathbf{1 . 4 6}$ to be implemented in legal terms as follows:

(1) a so-called 'income-inclusion' rule, which allows a State to include certain foreign income in its tax base if this income is taxed abroad below a minimum rate;

(2) an 'under-taxed payment' rule, which is intended to allow a State to refuse a tax deduction (for business expenses) or, alternatively, to levy a withholding tax if these payments are not taxed or are taxed below a minimum rate in the recipient's State of residence; 
(3) a so-called 'switch-over' provision which allows a State to amend tax advantages under a double tax agreement for such branches/ establishments if their taxation abroad is below a minimum tax rate;

(4) a so-called 'subject-to-tax' regulation for those income components where the underlying payments are undertaxed in relation to the minimum rate.

1.47 Public hearings on the two pillars were held in Paris on 21 and 22 November 2019 and 9 December 2019 respectively. Following the evaluation of the public discussions and the written comments submitted, the OECD will prepare further comments in the course of 2020, which will then result in concrete recommendations for action and implementation to the Member States. It is important to note that Pillars 1 and 2 will only exist as a political 'package'. Pillar 1 is essentially based on the demands of those source States which, according to the classical criteria for linking to the Pillar 1, can claim no or hardly any taxation rights for digital services. Pillar 2, on the other hand, is based on the demands of the classic residence States and serves as a kind of compensation for Pillar 1.

1.48 From the outset, the OECD is reported to have intended to summarize the findings of the consultations in a guidance paper by the end of January 2020, in order to then start further detailed work. On 31 January 2020, the paper, which was drafted by the Inclusive Framework on BEPS and thus with the participation of many non-OECD countries, was put online. ${ }^{53}$ In the paper, the Inclusive Framework explicitly acknowledges the preliminary work of the OECD, but identifies legal certainty with the least possible complexity as the central challenge of the ongoing work. In addition, a large number of legal and political issues need to be resolved. For example, the delimitation and differentiation of digital services is difficult in detail, the threat of double taxation must be prevented, and more thought must be given to binding dispute resolution mechanisms.

1.49 For the further work on Pillar 1, 11 working groups have been set up, which were to submit their reports by the end of 2020. Of particular interest in this context is the announcement that Pillar 1 may possibly be implemented via a further multilateral tax treaty. For Pillar 2, the paper of 31 January 2020 merely contained a progress report summarizing the current state of the debate on global minimum taxation. But here, too, the talks were progressing rapidly.

53 https://www.oecd.org/tax/beps/statement-by-the-oecd-g20-inclusive-framework-on-beps-january-2020.pdf. 
In January 2021, public consultation meetings were held on the blueprints of Pillar 1 as well as Pillar 2.54

\section{B. BEPS ACTION ITEM 12}

Action Item 12 of the above-mentioned BEPS Project gives, albeit without having a BEPS minimum standard authority, tax authorities the ability to obtain early information on potentially aggressive or abusive tax planning strategies and their users. The key goal of Action Item 12 is to 'react rapidly to close down opportunities for tax avoidance'. The BEPS Project recognizes that one of the key challenges faced by tax authorities is lack of timely, comprehensive and relevant information on potentially aggressive or abusive tax planning strategies. A mandatory disclosure regime provides tax administrations with the tools to obtain information much earlier than through the submission of tax returns and tax audits. Early identification of changes in taxpayer behaviour and the development of tax avoidance strategies, means that tax authorities will be able to respond and counter these threats by making timely and informed decisions on legislation, policy and regulation. ${ }^{55}$

The key outputs identified by the Report of Action Item 12 are: ${ }^{56}$

- Recommendations for the modular design of mandatory disclosure rules;

- A focus on international tax strategies and consideration of a wide definition of tax benefit to capture relevant transactions;

- Designing and putting in place enhanced models of information sharing for international tax strategies.

The OECD recognizes in the Report that existing strategies implemented by countries such as the US, the UK and Canada have reported a great deal of success. Action Item 12 therefore draws on the experience of these existing strategies, and sets out recommendations for designing an effective disclosure regime to counter the BEPS concerns of each country. The Report proposes a

54 https://www.oecd.org/tax/beps/oecd-g20-inclusive-framework-on-beps-invites-public-input-on-the-reportson-pillar-one-and-pillar-two-blueprints.htm.

55 The gist of the concept of tax avoidance is clearly linked to the possibility to obtain a tax advantage "by exploiting the friction between the form, which [the taxpayers] choose from those that do not trigger the liability to tax, and the substance, which is akin to events that would otherwise trigger the liability to tax', see Pistone, 'The meaning of tax avoidance and aggressive tax planning in European Union tax law: some thoughts in connection with the reaction to such practices by the European Union' in Dourado (ed.), Tax Avoidance Revisited in the EU BEPS context, IBFD, Amsterdam 2017.

56 See the Report under https://www.oecd.org/tax/mandatory-disclosure-rules-action-12-2015-final-report9789264241442-en.htm. 
modular approach to give tax authorities the flexibility to choose hallmarks and thresholds for disclosure which can be moulded to fit around the specific needs of the tax system. This will allow for maximum consistency between the OECD countries while being sensitive to the concerns of the domestic jurisdiction, as well as the costs for tax administrations and business. Along with the concern for domestic strategies, Action Item 12 aims to provide a way to target cross-border strategies which involves multiple parties deriving tax benefits in different jurisdictions.

1.53 It has been noted that existing strategies have received fewer disclosures in relation to international strategies, partly related to the way international strategies are structured, and can therefore operate below the relevant thresholds for disclosure. In response to this, the Report recommends that countries develop specific hallmarks to target cross-border BEPS outcomes that cause them concern, rather than target the mechanisms that are used to achieve them. In addition to this, taxpayers who enter intra-group transactions should be obliged to make inquiries to ascertain if the transaction has been specifically identified as reportable under the mandatory disclosure regime adopted by the home jurisdiction.

1.54 The Report also discusses the potential of the mandatory disclosure rules to act as deterrent and hence decrease the rate of BEPS in participating countries. Taxpayers who are considering entering into tax planning strategies will, in the eyes of the OECD, need to think carefully if they know that the strategy will need to be reported to the tax authorities and that they may also be subject to penalties if they fail to comply with their disclosure obligations. The market may also see a decrease in promoters offering such strategies given that the tax authority will be aware much earlier that the strategy has been developed and therefore the opportunity to implement the strategy itself could be short lived. With each jurisdiction drawing their focus towards collecting comprehensive and relevant information in relation to domestic and international tax strategies, there is potential for participating tax authorities to co-operate and share this information. By increasing collaboration and transparency on an international level, the proposals set out above aim to contribute to the fundamental goals of the BEPS Project.

1.55 If one compares the hallmarks used under DAC6 and Action Item 12, it is obvious that they largely use similar hallmarks and that both sets of rules also differentiate between generic and specific hallmarks. However, there are a number of hallmarks which were discussed in the BEPS Report that have not been given further notice under DAC6. They are summarized below. 
'Leasing arrangements': this hallmark draws on experience from UK law where tax arrangements involving leasing agreements are taken into account for purposes of the mandatory disclosure rules. ${ }^{57}$ In the first instance, the leasing agreement must relate to plant or machinery. Furthermore, at least one of the following additional conditions must be met: (i) At least one of the parties involved in the tax arrangement is entitled to capital allowances for the plant or machinery under UK law and another party is not subject to corporation tax; (ii) These are arrangements under which the lessor, by providing financial resources, is no longer exposed to the risk of non-payment otherwise incumbent on it; (iii) It is an arrangement of the lease either in the form of a sale and finance leaseback or under a lease and finance leaseback. In addition to being related to the leasing of plant and equipment and the fulfilment of at least one of the aforementioned conditions, the leased asset must exceed a value threshold in order to be subject to the reporting requirement. In each case, the lower of the lessor's costs and the market value of the plant or machinery is decisive. With regard to the value threshold, the British legislator differentiates between an individual and an overall view. The criterion is met by individual assets if their value is at least 10 million British pounds. However, the value threshold can also be met if the value of all the assets leased by the leasing included in the lease is at least 25 million British pounds. In addition, the lease agreement must not be a short-term agreement. Contracts with a maximum term of two years are considered to be short-term. Arrangements, such as options to extend the contract, are considered to extend the contract. Of particular interest for the possibilities of structuring a notification obligation is the fact that the British legislator refrains from a notification obligation if no promoter is involved and the arrangement is intended for a natural person or a small- or medium-sized enterprise.

'Employment schemes': This hallmark draws on experience from Irish law where for the purposes of the obligation to notify tax arrangements, the Irish legislator also refers to employment schemes. ${ }^{58}$ This indicator is aimed at tax arrangements relating to employment relationships in which income tax and social security contributions or corporation tax are to be avoided. Specifically, the employer, the employee or a third party involved in the employment relationship must be able to reduce, shift or at least expect the payment of tax. The Irish legislator identifies the tax avoidance potential associated with the indicator in particular in the definition of earned income. The term earned income is interpreted broadly and includes, for example, salaries, wages, fees; the specific designation is not important. This regulation is aimed, for

57 See Regs 13-17 of the UK Tax Avoidance Schemes Regulations 2006.

58 See Section 817DA (7) of the Irish Taxes Consolidation Act (Finance Act 2019 edition). 
example, at employee benefit trusts. Statutory exemptions and benefits, such as pension agreements, are not covered by this, however.

1.58 'Listed transactions/transactions of interest': This hallmark draws on experience from US law where a reporting obligation can be established if the taxpayer participates in a structure that is considered a so-called listed transaction. ${ }^{59}$ These are structures that have been classified by the US federal tax authority, the Internal Revenue Service (IRS), as a model for tax avoidance. Listed transactions, including a description of the arrangement, are published by the IRS. The US legislature presumes participation in a listed transaction if the tax return reflects the tax effects set forth in the description of a listed transaction or if the taxpayer has reason to believe that a tax benefit obtained by him is attributable to one of these arrangements. In addition, published descriptions of listed transactions may classify certain groups of taxpayers as participants regardless of the individual case. Closely related to listed transactions are the transactions of interest, which are also applied in US law. ${ }^{60}$ The latter are also published by the IRS. Unlike listed transactions, however, these are not necessarily tax avoidance models. Rather, these are arrangements which, in the view of the US tax authorities, have the potential to serve as a tax avoidance model, but a well-founded statement is not yet possible due to a lack of information. At a later point in time, tax arrangements considered to be transactions of interest may be classified as listed transactions or even as a model not aimed at tax avoidance.

1.59 'Arrangements involving hybrid instruments': This hallmark draws on experience from South African law where in the context of its reporting obligation for tax structuring, the law also focuses on hybrid equity instruments traded over-the-counter. ${ }^{61}$ In the view of the South African Ministry of Finance, these instruments entail the risk that income tax payments are reduced, avoided or deferred as a result of tax structuring approaches. Hybrid equity instruments include all shares that do not involve a capital participation and that the issuer can repurchase in full or in part within ten years, the holder has a comparable option or the holder also has a right of disposal within the ten-year period. This includes, for example, non-exchange-traded preference shares that can be repurchased within a period of up to ten years and must therefore be reported.

59 See $§ 1.6011-4$ b) 2) US Code of Federal Regulations.

60 See, for instance, the so-called Basket Contracts under US law (information can be obtained under https://www.irs.gov/businesses/corporations/transactions-of-interest).

61 See SARS, Reportable Arrangement Guide, 2005, p. 7 (information can be obtained under www.sars.gov. za/AllDocs/OpsDocs/Guides/LAPD-TAdm-G13\%20-\%20Reportable\%20Arrangement\%20Guide.pdf). 
'Contractual protection': This hallmark draws on experience from Canadian law where the characteristic of contractual protection provisions applicable in Canadian law is aimed at arrangements under which agreements are made to protect against the risks associated with tax structuring. ${ }^{62}$ It covers insurance policies or comparable protective arrangements that provide for indemnification, compensation or guarantees. The Canadian legislature ties this to either protecting a person from the loss of the tax benefit associated with the failure of a tax arrangement or paying or reimbursing him for expenses, fees, taxes, interest, penalties or similar amounts incurred in the event of litigation involving the tax arrangement. In either case, the promoter must promise some form of support in the event of litigation related to the tax benefit sought from the arrangement. Professional liability insurance is expressly not included here.

The reasons why these hallmarks have not been included in the Directive are manifold. Presumably, this is because the examples given above from the national laws of some countries are too specific, or because it was - in my view rightly - assumed that the added value of the information obtained as well as the deterrent effect were likely to be comparatively low. The added value is thus only to be seen in particular in the fact that the tax authorities can determine the prevalence of the respective hallmarks and use the knowledge gained through disclosure for purposes of tax declaration support.

\section{COUNCIL DIRECTIVE (EU) 2018/822 (DAC6)}

\section{Background}

As explained above, Action Item 12 of the OECD's BEPS project recommended that jurisdictions should introduce a regime for the mandatory disclosure of aggressive tax planning arrangements. However, the report does not set minimum standards and does not require implementation. Nevertheless, the EU Commission and Member States regarded disclosure of information on cross-border tax planning as consistent with the recent extension of tax transparency. Just as with ATAD I63 and II, ${ }^{64}$ the EU took momentum and quickly pushed forward parts of the BEPS Action Plan for the territory of the Union.

62 See Section 237.3 (1) Canadian Income Tax Act.

63 Council Directive (EU) 2016/1164 of 12 July 2016 laying down rules against tax avoidance practices that directly affect the functioning of the internal market.

64 Council Directive (EU) 2017/952 of 29 May 2017 amending Directive (EU) 2016/1164 as regards hybrid mismatches with third countries. 
1.63 The EU Council adopted the Directive ${ }^{65}$ at a meeting of the Economic and Financial Affairs Council on 25 May 2018, without discussion. Member States had until 31 December 2019 to transpose it into national law. The final version of the Directive (EU 2018/822) was published in the Official Journal on 5 June 2018 and so came into force from 25 June 2018. Under the Directive, Member States need to require 'intermediaries' (such as banks, accountants, lawyers and, last but not least, tax advisers) to report on certain cross-border tax planning arrangements, such that the Member State will be in a position to, and will be required to, exchange such information with other Member States.

1.64 The Directive, which amended the existing Directive on Administrative Cooperation (DAC) for the sixth time (hence the abbreviation 'DAC6'), was first put forward by the EU Commission in June 2017. It built on other recent tax transparency developments, including those requiring exchange of information concerning tax rulings and proposals for public disclosure of tax information on a country-by-country basis. It was also undoubtedly influenced by high-profile leaks, including the release of the so-called Panama Papers. ${ }^{66}$ The legal basis for the Directive is Art 115 of the Treaty on the Functioning of the $\mathrm{EU}$ (TFEU) on the basis that lack of transparency facilitates the activities of intermediaries in promoting cross-border tax planning and, as a consequence, this distorts competition in favour of low-tax jurisdictions and businesses which engage in such activities.

\section{DAC6 in a nutshell}

1.65 The rules of the Directive will in detail be explained in this handbook, so that at this stage a quick overview of the rules in question will do.

\section{(a) Reporting duties for intermediaries regarding cross-border tax arrangements}

1.66 The rules apply to a 'reportable cross-border arrangement'. A cross-border arrangement requires the arrangements to involve two or more Member States or a Member State and a third country, i.e., wholly domestic arrangements will not be in scope (although may then be subject to national regimes). Such an arrangement will be 'reportable' if it satisfies at least one of a range of 'hallmarks' which are listed in Annex IV to the Directive. It is the hallmarks

65 Council Directive (EU) 2018/822 of 25 May 2018 amending Directive 2011/16/EU as regards mandatory automatic exchange of information in the field of taxation in relation to reportable cross-border arrangements.

66 In that regard, the Directorate-General for Internal Policies of the Union (European Parliament) published a Report on 7 June 2017 called The impact of schemes revealed by the Panama Papers on the economy and finances of a sample of Member States. 
which are used, essentially, as a proxy for identifying 'aggressive tax planning'. However, the term 'arrangement' is not defined at all.

The Directive requires Member States to introduce rules to require intermediaries' to provide information to the competent tax authority on a reportable cross-border tax arrangement within 30 days beginning on the earlier of: (i) the day after the arrangement is made available for implementation; (ii) the day after the arrangement is ready for implementation; or (iii) the first step of the arrangement occurs.

For these purposes, an 'intermediary' means any person that 'designs, markets, organises, makes available for implementation or manages the implementation' of a reportable cross-border arrangement. 'Intermediaries' also covers any such person that:

knows or could be reasonably expected to know that they have undertaken to provide, directly or by means of other persons, aid, assistance or advice with respect to designing, marketing, organising, making available for implementation or managing the implementation

of a reportable cross-border arrangement. However, only intermediaries that are incorporated, tax resident, registered with a professional association or have a permanent establishment in a Member State are within the scope of the rules.

The most obvious intermediaries will, of course, be accountants, lawyers and other tax advisers involved in advising clients on their tax affairs. However, the definition goes wider and will catch any person involved in assisting or organizing the arrangements, and may well apply to banks and other financial advisers. In particular, compared to the original June 2017 text, it is no longer a requirement that an intermediary be involved in the provision of tax advice in relation to the arrangements. Any lawyer or bank, for example, involved in the implementation of such arrangements will be an intermediary even if they have no involvement in advising on the tax aspects of the arrangements. Where (as will often be the case) there is more than one intermediary involved, then in principle all intermediaries will have a reporting obligation, unless they can show that the relevant reporting obligation has been fulfilled yet by another intermediary. The Directive provides that the obligation to report on a 'cross-border reportable arrangement' will be moved to the taxpayer where either the intermediary is protected from disclosure by legal professional privilege or where there is no EU based intermediary involved. 
1.70 Where a Member State receives information concerning a cross-border reportable arrangement from an intermediary or taxpayer, that State will then need to exchange that information automatically with other Member States, including a range of details concerning the arrangements (such as summary of the arrangements, their value, identification of persons in other Member State involved, details of the hallmarks, implementation dates, etc.). It has to be noted that exchange will be with all other Member States, rather than just those implicated in the reportable cross-border arrangement in respect of which disclosure has been made. It was intended that the Commission will set up a 'central directory' where the information can be communicated to satisfy this requirement.

1.71 In the case of 'marketable arrangements', Member States must require a periodic report from intermediaries every three months providing an update on the reportable information. Member States are furthermore required to provide for penalties that are 'effective, proportionate and dissuasive' for failure to comply with reporting obligations under the domestic implementation of the Directive.

\section{(b) Hallmarks}

1.72 Whilst the Recitals to the Directive state that the measures are aimed at 'aggressive' cross-border tax planning arrangements, ${ }^{67}$ that expression is not used in the wording of the legislation at all. Instead, the Directive seeks to use a series of hallmarks to identify the arrangements concerned. These hallmarks fall into two groups.

1.73 First Group: Arrangements which must satisfy the so-called main benefit test and have a generic hallmark or specific hallmark linked to the main benefit test:

- The so-called generic hallmarks include the inclusion of a confidentiality condition relating to the tax advantage, a fee based on the tax advantage or the use of standard form documentation;

- The so-called specific hallmarks include loss buying arrangements, converting income to capital, circular transactions and arrangements involving deductible cross-border payments between associated entities where the recipient is substantially untaxed.

1.74 In either case the main benefit test will be satisfied where it can be established that 'the main benefit or one of the main benefits which, having regard to all

67 The word 'aggressive' is used 18 [sic!] times in 20 paras of the Recitals! 
relevant facts and circumstances, a person may reasonably expect to derive from an arrangement is the obtaining of a tax advantage'. It should be noted that 'tax advantage' is undefined and there is no legislative requirement that the advantage be one that is not one intended to be conferred on a taxpayer.

Second Group: Arrangements which have specific hallmarks related to crossborder transactions, transfer pricing or which seek to circumvent automatic exchange of information in the EU, including:

- Arrangements involving the availability of depreciation in more than one jurisdiction, multiple claims for double tax relief on the same income and transfers of assets where there is a material difference in the amount treated as consideration;

- Transfer pricing arrangements involving the use of unilateral safe harbour rules, involving hard-to-value intangibles or involving a crossborder transfer of functions/risks/assets where the projected annual EBIT for the following three years is less than $50 \%$ of the projected annual EBIT in the absence of such a transfer; and

- Arrangements to undermine reporting obligations under EU law or equivalent arrangements on automatic exchange or which take advantage of the absence of such legislation or agreements as well as arrangements broadly involving 'a non-transparent legal or beneficial ownership chain'.

In this second category of hallmarks, the arrangements do not also need to meet the main benefit test. It should also be noted that the DAC does not, and therefore the new rules will not, apply to value added tax, customs duties, excise duties or to compulsory social security contributions.

\section{(c) Transitional rules}

Whilst the rules are only forward looking in the sense that existing tax planning arrangements in place prior to the enactment of the Directive are not affected, the Directive does contain a transitional regime. Under these transitional rules, any cross-border arrangements the first step of which was implemented between the date of entry into force of the Directive (25 June 2018) and the date of application of the Directive (1 July 2020) (when the full rules had to be implemented under the original plan of the EU) had to be disclosed by 31 August 2020. Therefore, although the first notifications were not due until August 2020, these notifications had to cover the period from the entry into force of the Directive (25 June 2018) onwards. Taxpayers and intermediaries therefore had to consider how they will track relevant arrangements to enable them to file these notifications. This proved to be problematic in the absence of national implementing legislation. In particular, in the 
absence of domestic legislation or guidance, it was hardly possible to know how widely national tax authorities would intend to interpret the rules.

\section{JUSTIFICATION OF MANDATORY DISCLOSURE RULES}

1.78 The tax policy function of disclosure rules is rather obvious: With the introduction of mandatory disclosure rules for tax arrangements, the legislator wants to enable the tax administration to react to tax saving models earlier and in a more structured manner than before, since this would serve to maintain the uniformity of taxation and to avoid structural collection deficits due to non-co-ordinated tax law systems. In the light of this, it is very clear that the goal of closing loopholes in tax laws that are contrary to the system and thus counteracting tax avoidance is legitimate in principle. The widespread exploitation of such loopholes not only affects the uniformity of taxation, it is also problematic from an economic perspective as a source of inefficient behavioural guidance and a cause of distortions of competition between companies. The tax policy assessment of such rules depends, however, on the extent to which they can contribute to the achievement of this legitimate objective, whether its benefits can justify the additional effort caused on the part of all parties involved, and how any undesirable side effects can be avoided.

1.79 The central task of a tax policy-oriented notification system is to inform the legislator as early as possible about the use of existing loopholes in the tax laws. The notification obligations are primarily intended to give the legislator a time advantage. On the one hand, this concerns facts and circumstances which should, from the viewpoint of the legislator, ideally be taxed, but which are not taxable if the tax laws are applied literally. On the other hand, it is a matter of (international) tax arbitrage that does not exploit loopholes in one system, but rather incongruities (like qualification conflicts) between several tax systems, e.g., in order to generate situations of double non-taxation. By means of the information obtained through the reporting requirements, the Member States are to be enabled 'to react promptly against harmful tax practices and to close loopholes by enacting legislation or by undertaking adequate risk assessments and carrying out tax audits'. ${ }^{68}$ It also has to be noted that for the EU Commission and many Member States, the objective of supporting tax assessments was also particularly important and that, in accordance with the objectives mentioned above, the reporting can not only be the reason for legislative measures, but also for special focal points in ongoing tax audits. 
However, it should be questioned to what extent there is actually an information deficit on the part of the legislator. For example, tax arrangements often only become widespread after a decision by a fiscal court, which reveals a legal loophole and at the same time provides these arrangements with a reasonably legally secure basis. Also, many tax arrangements are openly discussed in professional tax law journals and at tax conferences, since tax advisers have an interest in revealing their expertise to potential clients and in substantiating and testing new ideas in a framework that is not yet relevant to liability. Often enough, the legislator does not even take gaps known to him as a reason to intervene to change the law, sometimes even for years or decades. After all, although there may be valid reasons for the introduction of a reporting obligation system, the danger of its proliferation must be pointed out at the same time. In many countries with mandatory reporting systems, a tendency towards constant expansion can be observed. In addition, the objective of indirectly discouraging reportable arrangements by means of the mandatory reporting system can be identified. If one reads the Recitals of the Directive, the aspect of deterrence is explicitly stressed or at least clearly shines through between the lines. ${ }^{69}$

A well-balanced system of mandatory reporting obligations would therefore

have to ensure in its basic orientation and detailed design that, as far as possible, only arrangements with actual tax policy relevance are reported. This requires a cautious and sufficiently precise definition of the personal and material scope of application as well as the scope of the reporting in detail. The reporting requirements must not be made onerous beyond what is necessary to inform the legislator. Otherwise, in addition to an inadmissible excessive demand on those required to report, there is also a risk of a flood of information that the already overburdened tax administrations will hardly be able to cope with.

69 See, for instance, Para 7 of the Recitals:

It is acknowledged that the reporting of potentially aggressive cross-border tax-planning arrangements would stand a better chance of achieving its envisaged deterrent effect where the relevant information reached the tax authorities at an early stage, in other words before such arrangements are actually implemented.

See also Para 11:

Considering that the reportable arrangements should have a cross-border dimension, it would be important to share the relevant information with the tax authorities in other Member States in order to ensure the maximum effectiveness of this Directive in deterring aggressive tax-planning practices.

Also Para 13:

In order to minimise costs and administrative burdens both for tax administrations and intermediaries and to ensure the effectiveness of this Directive in deterring aggressive tax-planning practices, the scope of automatic exchange of information in relation to reportable cross-border arrangements within the Union should be consistent with international developments. 
1.82 Another question is whether it is sensible and desirable to regulate everything that is possible on an EU level, given the fact that the disclosure rules have a close link to the growing tax competition between countries, as explained above. Economics examines the consequences of tax harmonization under the question 'tax harmonization vs. tax competition'. In the following, essential arguments for the respective positions are summarized.

1.83 One if not the most essential argument for harmonization is the so-called 'race to the bottom' argument. ${ }^{70}$ According to this argument, in a tax competition, States undercut each other in terms of tax rates in an effort to attract investors. In such a prisoner's dilemma, a Nash-equilibrium results in tax rates that are no longer sufficient to finance government spending. Indeed, over a longer time frame, declining tax rates are found across Europe and the world. However, there is a lack of empirical evidence that current tax rate levels continue to decline. Moreover, academic literature fails to show the relationship between tax competition and tax rate reductions. At present, therefore, there is no hard evidence of a harmful tax-cutting race at any price. Whether this will continue in the future remains to be seen in the light of current post-BEPS developments. For example, as a result of the 2018 tax reform, the US offered relatively low tax rates when tax benefits were used to improve the investment climate in the US. This problem may, however, only arise in the US as a result of the latest tax reform if government revenues are no longer sufficient to finance government spending.

1.84 In addition to the lack of empirical evidence, the model of tax competition is also criticized as being too one dimensional. Rather, States are not in a tax competition per se, but in a location competition. In this context, companies consider not only the expenditure side, but also the quid pro quo. Following the 'value for money' concept, a State with low tax rates would not necessarily be preferred if the infrastructure provided is proportionately less well equipped. Another argument in favour of tax competition assumes that tax competition between States has a disciplinary effect on government spending. It protects citizens from an overly greedy State that acts as a 'leviathan' and maximizes its State activity. In the case of tax competition, however, the State must keep an eye on spending and cannot develop activities without any restraint whatsoever. ${ }^{71}$

70 See Wildasin, Journal of Public Economics 1988, p. 229; Oates/Schwab, Journal of Public Economics 1988, p. 333.

71 See Brennan/Buchanan, Cambridge University Press 1980, p. 13; Frey, CESifo Working Paper Series 2002, p. 11. 
As a result of the adjustment of a centralized monetary and interest rate policy and the abolition of exchange rates within the EU, States have little degree of freedom at the macroeconomic level within the EU. Expenditure policy (budget) and the revenue side (taxes and levies) are the last remaining controllers. If, as a result of harmonization, these adjustment mechanisms are no longer available to the State, it is deprived of its degrees of freedom with regard to macroeconomic developments. This can have spillover effects on the labour market and price developments. Moreover, an overly harmonized tax policy ignores regional differences in consumption, for example, through demand elasticities, but also with regard to infrastructure spending through different levels of infrastructure and different expenditures, for example, depending on whether there is a territorial State. Furthermore, a uniform tax policy does not take into account differences with regard to State redistribution. Finally, for example, one could call for only those tasks to be assumed at the EU level that the States cannot perform, in accordance with the subsidiarity principle. In the case of tax revenues, meanwhile, States would be better positioned to decide how to contribute to the European budget and which taxes to use for this purpose.

These arguments show that there is a link between revenues and expenditures.

A detached tax revenue policy from the expenditure side has neglected local specificities. Moreover, the equivalence principle is violated. This means that taxpayers should also be the beneficiaries. Arguments that the equivalence principle is violated in the EU anyway by cross-border spillover effects, tax shifting through transfer pricing and tax subsidies for non-residents could be questioned, however, insofar as the former are not observable and that unequal tax subsidies should be solved, for instance, through State aid law, but not through tax harmonization.

\section{E. EU LAW LEGITIMATION}

With the Treaty of Maastricht, ${ }^{72}$ the foundation stone of the European Union was laid on 7 February 1992. The European Community became the European Union. The aim of the treaty was to prepare the European Monetary Union and to introduce elements of a political union (citizenship, common foreign and domestic policy). Even before that, the Single European $\mathrm{Act}^{73}$ of 1 July 1987, forced the implementation of the European Single Market on 1 January 1993. It called programmatically for an area without internal

72 https://europa.eu/european-union/sites/europaeu/files/docs/body/treaty_on_european_union_en.pdf.

73 https://eur-lex.europa.eu/legal-content/EN/TXT/?uri=LEGISSUM\%3Axy0027. 
borders. The four freedoms (freedom of movement of persons, goods, services and capital) had already been claimed in the 1957 Treaty of Rome, ${ }^{74}$ but in practice they had been implemented only inadequately. With regard to tax policy, the Treaty of Lisbon 75 (entry into force on 1 December 2009) in Arts 110 et seq. brought about specifications with a view to tax policy. Against the background of the functioning of the internal market, legislative powers were granted in the area of indirect taxation.

1.88 However, the legislative competence for direct taxation has not been transferred to the EU. Only with recourse to Art 115 TFEU can the EU issue directives on direct taxation:

Without prejudice to Article 114, the Council shall, acting unanimously in accordance with a special legislative procedure and after consulting the European Parliament and the Economic and Social Committee, issue directives for the approximation of such laws, regulations or administrative provisions of the Member States as directly affect the establishment or functioning of the internal market.

The content of the directives limits national legislators to the extent that national regulations must take into account the content of the directives - in the sense of minimum standards - or adapt existing unilateral regulations that fall short of the level of protection envisaged by the EU. Regulations that go beyond this can be enacted provided that they do not constitute a violation of the fundamental freedoms codified in Arts 45 et seq. TFEU. Furthermore, national regulations must not constitute selective aid within the meaning of Arts 107 et seq. TFEU.

1.89 The cornerstones of the EU are the four fundamental freedoms, which were already laid down in the Treaties of Rome. The creation of the single European market as a result of the Single European Act has given them their specific form. Against this background, the legislative competence in the area of indirect taxes is understandable. With regard to direct taxes, directives can only be issued under Art 115 TFEU if they have a direct impact on the establishment or functioning of the internal market. This requires a unanimous decision by the Council. National tax policies are thus given room to manoeuvre and EU tax policy is given a narrow framework with a view to convergence. The directives mainly from the 1990s (Merger Directive, ${ }^{76}$

74 https://eur-lex.europa.eu/legal-content/EN/TXT/?uri=LEGISSUM\%3Axy0023.

75 https://eur-lex.europa.eu/legal-content/EN/TXT/?uri=celex\%3A12007L\%2FTXT.

76 Council Directive 2009/133/EC of 19 October 2009 on the common system of taxation applicable to mergers, divisions, partial divisions, transfers of assets and exchanges of shares concerning companies of different Member States and to the transfer of the registered office of an SE or SCE between Member States. 
Interest and Royalties Directive ${ }^{77}$ and Parent-Subsidiary Directive ${ }^{78}$ ) appear to be directly beneficial to the functioning of the internal market. Whether the current developments (ATAD I79 and II, ${ }^{80}$ significant digital presence, ${ }^{81}$ digital $\operatorname{tax}^{82}$ and mandatory disclosure rules as well) have a direct impact on the functioning of the internal market is questionable, however, although the Directive in its Preamble explicitly refers to Art 115 TFEU (for the direct taxes covered by the Directive) as well as to Art 113 TFEU (for the indirect taxes covered by the Directive).

Apart from this it is on principle questionable whether the mandatory disclosure rules violate EU law and the European fundamental freedoms in particular. ${ }^{83}$ It should be beyond dispute that a reporting obligation that is specifically linked to cross-border tax arrangements which fall within the scope of protection of a fundamental freedom guaranteed under the TFEU constitutes a restriction of this fundamental freedom that requires justification. The decisive question is again whether this restriction can be justified by overriding reasons in the general interest according to the standards set by the ECJ. While individual authors affirm a justification, this is denied by the majority in academic literature.

In my view, the latter is more convincing. The justification recognized by the ECJ of ensuring effective tax supervision ${ }^{84}$ is not relevant because this purpose is not pursued at all with the reporting obligation. Rather, according to Recital 2 of the Directive, it is intended to enable public authorities to take prompt action against harmful tax practices and to close loopholes by means of legislation or by means of appropriate risk assessments and the performance of tax audits in order to counteract the considerable decline in tax revenues in the Member States. However, fiscal interests alone and the goal of preventing tax revenue shortfalls are by no means sufficient to justify a restriction of

77 Council Directive 2003/49/EC of 3 June 2003 on a common system of taxation applicable to interest and royalty payments made between associated companies of different Member States.

78 Council Directive 2011/96/EU of 30 November 2011 on the common system of taxation applicable in the case of parent companies and subsidiaries of different Member States.

79 Council Directive (EU) 2016/1164 of 12 July 2016 laying down rules against tax avoidance practices that directly affect the functioning of the internal market.

80 Council Directive (EU) 2017/952 of 29 May 2017 amending Directive (EU) 2016/1164 as regards hybrid mismatches with third countries.

81 Proposal for a Council Directive laying down rules relating to the corporate taxation of a significant digital presence, $\operatorname{COM}(2018) 147$ final.

82 Proposal for a Council Directive on the common system of a digital services tax on revenues resulting from the provision of certain digital services, $\operatorname{COM}(2018) 148$ final.

83 See in general Blum/Langer, At a Crossroads: Mandatory Disclosure under DAC-6 and EU Primary Law Part 1, European Taxation, Vol. 59, No. 6 as of 13 May 2019.

84 See in this regard fundamentally the ECJ judgment as of 15 May 1997 - C-250/95, Futura Participations, ECLI:EU:C:1997:239. 
fundamental freedoms, ${ }^{85}$ especially since this concerns the tax revenue of the individual national States and thus also lacks any connection to the internal market. Nor does the justification of preventing tax abuse apply. This is because by no means all tax arrangements that exhibit one of the characteristics listed in Annex IV of the Directive can be regarded as abusive. In any case, the regulation does not provide the proof required by the case law of the $\mathrm{ECJ}{ }^{86}$ that there is no abuse in the specific case.

1.92 In addition, the European reporting obligation is incompatible with the fundamental rights of the EU Charter of Fundamental Rights (CFR). ${ }^{87}$ Insofar as the obligation is imposed on intermediaries, the reporting obligation violates the freedom to exercise one's profession under Art 15 (1) CFR and the freedom to conduct a business under Art 16 CFR. This is because it not only means that professionals are called upon to perform governmental tasks free of charge, but also massively interferes with the client-attorney relationship and the professional confidentiality obligation of the professionals under professional law. These serious encroachments on fundamental rights caused by the reporting obligation also cannot be justified according to the standard of Art 52 (1) sentence 2 CFR. The goal of using intermediaries or even the taxpayers themselves free of charge to plug loopholes in tax laws cannot per se constitute a legitimate goal that could justify encroachments on fundamental rights under the CFR. Rather, the ECJ also explicitly concedes to every taxpayer the right to organize his activity in such a way that he keeps his tax liability within limits. ${ }^{88}$ The objective pursued by the European reporting obligation, namely to protect the tax revenue of the national States, cannot be a purpose permissible under EU law from the outset due to the lack of an internal market reference. Moreover, the reporting obligation is not necessary because alternative options for action exist for the Member States.

1.93 Finally, since the notification requirements under the Directive only apply to cross-border transactions, they are suspected of infringing the fundamental freedoms of the TFEU. Secondary law provisions such as Directives must also be reviewed in the light of the fundamental freedoms of the TFEU, ${ }^{89}$ at least as long as no final harmonization has taken place through the Directive. However, this argument was rejected very early on by the EU Commission,

85 See ECJ judgment as of 8 March 2001 - C-397/98, Metallgesellschaft und Hoechst, ECLI:EU:C:2001:134.

86 See ECJ judgment as of 11 March 2004 - C-9/02, Lasteyrie du Saillant, ECLI:EU:C:2004:138.

87 The Charter of Fundamental Rights of the European Union brings together the most important personal freedoms and rights enjoyed by citizens of the EU into one legally binding document. The Charter was declared in 2000, and came into force in December 2009 along with the Treaty of Lisbon.

88 See ECJ judgment as of 21 February 2006 - C-255/02, Halifax, ECLI:EU:C:2006:121.

89 See ECJ judgment as of 18 September 2003 - C-168/01, Bosal, ECLI:EU:C:2003:479. 
which - in my view rightly - already denies unequal treatment due to a lack of comparability between domestic and cross-border tax planning models, because the latter only work when certain tax jurisdictions are combined. ${ }^{90}$ If however, one would refer to the purpose of the Directive, i.e., the gaining of knowledge about unwelcome arrangements, which is indeed the same for domestic and cross-border arrangements, the ECJ would probably challenge on justification level the reason to prevent tax abuse. ${ }^{91}$ In the context of the principle of proportionality, at least some of the hallmarks are rather doubtful.

\section{F. PROBLEMS/STRUCTURE OF DISCLOSURE OBLIGATIONS AND USE OF THIS HANDBOOK}

Unfortunately, the DAC6 Directive was approved unanimously by the Member States and thus had to be implemented in their national tax laws respectively. This was unfortunate for many reasons:

- The Directive is in general at (or in places beyond) the limit of what language is capable. If the legislator cannot express precisely and clearly where provisions are aiming at and what the meaning of a specific provision is, the legislator should refrain from approving the law.

- The justification of the Directive is unclear. According to the Recitals, the EU legislator had the idea of closing loopholes in the national tax laws of Member States through information and transparency. If one reads the Recitals, however, the aspect of deterrence is explicitly stressed or at least clearly shines through between the lines. But to be very clear: Deterrence should not be recognized as a sufficient justification from a constitutional law point of view.

- The legislative process was extremely short. This inevitably leads to mistakes and loopholes (for instance there are hardly any rules on multiple intermediaries and subcontracts).

- It is questionable whether mandatory disclosure rules have a direct impact on the functioning of the internal market, despite the fact that the Directive in its Preamble explicitly refers to Art 115 TFEU (for the direct taxes covered by the Directive) as well as to Art 113 TFEU (for the indirect taxes covered by the Directive).

90 See European Commission, C(2017) 7713 final, https://ec.europa.eu/transparency/regdoc/rep/3/2017/EN/ C-2017-7713-F1-EN-MAIN-PART-1.PDF.

91 For an assessment of the Directive's relation to other existing tools of reporting and a confrontation with the freedoms of establishment and services see Bart Peeters, DAC 6: An Additional Common EU Reporting Standard?; World Tax Journal, Vol. 12, No. 3 as of 3 September 2020. 
- There is a lot of misconception around the hallmarks. Apart from the fact that many of the hallmarks have, in theory and practice, no connection to aggressive tax planning at all, the wording of many hallmarks is rather vague. The broad wording of the hallmarks does lead to their severe misinterpretation and to excessive tendencies in the application of the Directive.

- It is very doubtful whether the objective intended by the Directive can be achieved and justify the high compliance costs and administrative burdens on taxpayers.

- The reporting obligations will lead to a flood of reportings that can neither be evaluated by the tax authorities in a timely manner nor comprehensively in terms of content. The collection of senseless, unused data, however, raises the question of the constitutionality of the regulations.

1.95 It is therefore to be hoped (presumably as a pious hope) that the EU legislator could soon withdraw the Directive or at least make it more targeted or more practicable. This hope is backed by Art 27 Para 2 of the Directive, according to which every two years after 1 July 2020, the Member States and the Commission shall evaluate the relevance of Annex IV and the Commission shall present a report to the Council. That report shall, where appropriate, be accompanied by a legislative proposal.

1.96 Going forward and for the time being, however, taxpayers will have to comply with the rules that have been implemented in the Member States on the grounds of the Directive. In many Member States reportings have been performed based on the transitional rules, and taxpayers and intermediaries are already in the midst of the normal, ongoing reporting procedure. It goes without saying in this context that these reportings have to be done in accordance with the national laws of the respective Member State and not with the Directive as such, since the Directive had to be transformed into national law. However, the Directive is important for a better understanding of the national laws and also for their interpretation (in conformity with EU law). This Handbook is intended to provide the necessary knowledge for this.

1.97 Figure 1.1 shows a decision tree to determine the obligation to notify: 
Decision Chart Mandatory Disclosure Rules under DAC6

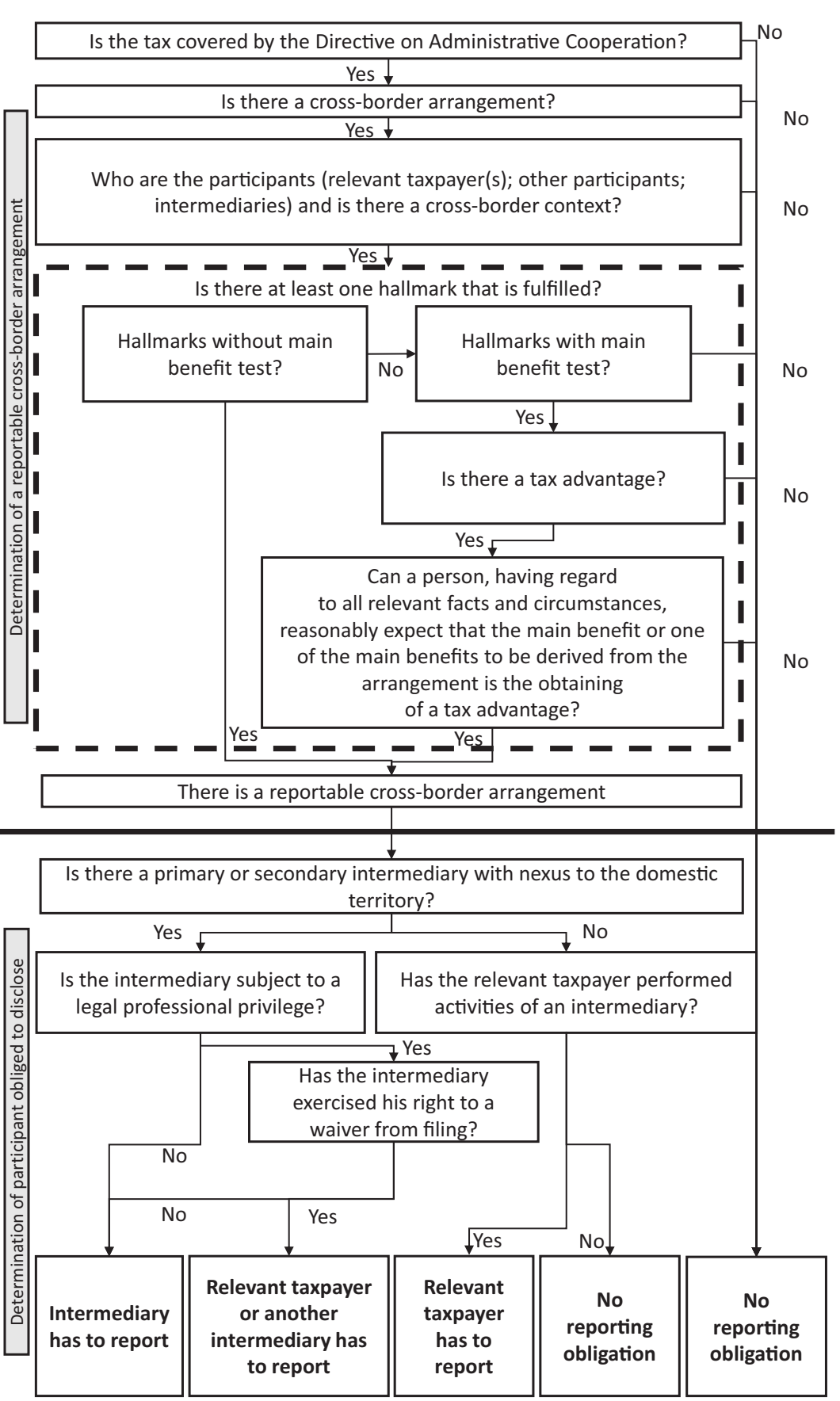

Figure 1.1 Decision chart mandatory disclosure rules under DAC6 
1.98 This Handbook can be used alongside this decision tree. After the introduction (this Chapter 1), Chapter 2 explains the term 'intermediary' and other participants to an arrangement. It also describes the taxes that are covered by the Directive. Art 3 Para 11 lit. d) of Council Directive 2011/16/EU sets forth in this context that income derived from the activity of the legal arrangement must be 'subject to any of the taxes covered by this Directive'. Chapter 3 deals with cross-border arrangements, and Chapter 4 with hallmarks, which makes the cross-border arrangement a reportable cross-border arrangement. Chapter 5 analyses the triggering events and timelines that have to be obeyed, and Chapter 6 has a closer look at the formal reporting procedure and the specific person that has to report. Chapter 7 explains, inter alia, the required content of the reporting, before Chapter 8 dares to insinuate on possible future developments. Chapter 9 shows the status of implementation in other Member States. The Handbook closes with Chapter 10 and the Reprint of relevant provisions from the 'Directive on Administrative Cooperation', as amended by DAC6. It has to be noted that this Handbook in part relies on the available administrative guidelines issued by Tax Authorities of Member States in order to ensure the best possible practical approach. 